\title{
Expanding the knowledge base on actual nutrition as an element of the system of alimentary-dependent diseases prevention.
}

\author{
Larisa Mayurnikova ${ }^{1}$, Anna Zirka ${ }^{1}$, Arkady Koksharov ${ }^{1,},{ }^{*}$, Nikolay Gornikov ${ }^{1}$, and Tatyana \\ Krapiva $^{1}$
}

${ }^{1}$ Kemerovo State University, 650000 Kemerovo, Russia

\begin{abstract}
The work presents a multi-aspect model of alimentarydependent diseases (ADD) prevention, which demonstrates the participants in this process and their priority tasks. A method is proposed based on the use of indicators for assessing the iodine-containing products contribution to the nutritional value of diets. Calculations were performed on a micronutrient - iodine, the deficiency of which causes the most common by depth and width ADD - thyroid pathology. To assess the iodine replenishing potential of raw fish and non-fish sea foods with the human diet, indicators were developed that account along with the iodine content in $100 \mathrm{~g}$ of product, the factors that directly or indirectly affect the digestibility and the economic feasibility of some of the most in-demand fish varieties. Selected factors: native iodine content in the product; qualitative and quantitative composition of synergistic nutrients for its digestibility in the body. Deviations of the reference data on the content of iodine in fish and non-fish products were found, which on average amounted to about $45 \%$, which is a significant loss that must be taken into account when using the calculated method of actual nutrition study.
\end{abstract}

\section{Introduction}

Modern challenges in nutritiology require a rethinking of the methodological approach to the prevention of alimentary-dependent diseases (ADD) in Russia. Prevention of ADD in various population groups is a multi-aspect task. Aspects need to be identified and considered at the following stages: design of specialized food products (SFP), production and bringing them to the consumer (market) in the aggregate of decisions made by participants in this process $[1,2,3]$. Participants and characteristics of ADD prevention aspects are presented in table 1.

Table 1. Multi-aspect model of alimentary-dependent diseases prevention

\begin{tabular}{|l|l|l|}
\hline $\begin{array}{l}\text { Research organizations, } \\
\text { bodies controlling nutrition } \\
\text { and health issues, scientific } \\
\text { and } \\
\text { organizations educational }\end{array}$ & $\begin{array}{l}\text { Food and processing enterprises, } \\
\text { public catering enterprises, small } \\
\text { innovative enterprises }\end{array}$ & $\begin{array}{l}\text { Specialty food market } \\
\text { (commercial, social) }\end{array}$ \\
\hline
\end{tabular}

*Corresponding author: koksharov.arkadiy@mail.ru 


\begin{tabular}{|c|c|c|}
\hline \multicolumn{3}{|c|}{$\begin{array}{l}\text { 1. State regulation of ADD prevention } \\
\text { - State policy as a priority prevention strategy; } \\
\text { - Federal and regional prevention programs. } \\
\text { 2. Support program of participants collaborations on priority scientific and technological areas of } \\
\text { research }\end{array}$} \\
\hline $\begin{array}{l}\text { Scientific research based on } \\
\text { the relationship of different } \\
\text { branches of knowledge to } \\
\text { gain new knowledge about } \\
\text { ADD problem }\end{array}$ & $\begin{array}{l}\text { Understanding the competitiveness } \\
\text { of healthy food products (SFP) for } \\
\text { implementation and production } \\
\text { purposes }\end{array}$ & $\begin{array}{l}\text { Formation of the consumer } \\
\text { market of healthy food } \\
\text { products }\end{array}$ \\
\hline $\begin{array}{l}\text { SFP design in the "from idea } \\
\text { to consumer" system }\end{array}$ & $\begin{array}{l}\text { Interaction with scientific and } \\
\text { educational institutions } \\
\text { update/expand the product range }\end{array}$ & \\
\hline $\begin{array}{l}\text { Design of SFP taking into } \\
\text { account the potential of food } \\
\text { and public catering } \\
\text { enterprises }\end{array}$ & $\begin{array}{l}\text { The demand for SFP in conjunction } \\
\text { with the NOO }\end{array}$ & $\begin{array}{l}\text { Communication with } \\
\text { consumers to inform and } \\
\text { promote SFP }\end{array}$ \\
\hline $\begin{array}{l}\text { Creation of SIE for the } \\
\text { development of new SFP } \\
\text { technologies }\end{array}$ & SFP & $\begin{array}{l}\text { Development of pricing } \\
\text { mechanism for SPS }\end{array}$ \\
\hline \multicolumn{3}{|c|}{$\begin{array}{l}\text { Epidemiology of nutrition } \\
\text { - Determination of nutritional value contribution of products to the nutritional value of the diet, } \\
\text { before preventive programs implementation; } \\
\text { - Evaluation of new SFP preventive effectiveness; } \\
\text { - Determination of nutritional value contribution of new SFP with therapeutic and preventive } \\
\text { effectiveness to nutritional value of the diet after preventive programs implementation. }\end{array}$} \\
\hline
\end{tabular}

The most common alimentary-dependent diseases in Russia, as in many other countries, are diseases associated with iodine deficiency in the diet. The problem of iodine deficiency in the diet is "historical", since the first scientific data on the effect of iodine deficiency on $\mathrm{ADD}$ formation were indicated in the literature at the beginning of the XX century $[4,5,6]$. According to nutritionists and in the areas of forecasting the scientific research prospects in the field of nutrition and health, the issues of iodine deficiency and ways to reduce it occupy a leading position [1].

It is known that modern problems require a scientifically based approach based on the analysis of aspects of the problem (table 1), identification of cause-and-effect relationships, new methodological solutions and their testing [7]. In the methodology of ADD prevention, the role of exploratory research is important, aimed at analyzing the history of the problem, existing solutions and their correction taking into account the specifics of the current state.

Classical epidemiology of nutrition, as one of the directions of nutritiology, includes three stages:

- study of the actual nutrition of different population groups (calculation method);

- provision of the human body with the necessary nutrients in order to identify compliance with the norms of physiological needs;

- identification of the depth and prevalence of deficits and, as a result, the forecast of ADD formation.

It is of interest to study the correspondence of reference books, guidelines and recommendations used in the epidemiology of nutrition to the real situation.

\section{Materials and methods}

The object of the study was the data of the chemical composition directory for a homogeneous group of food products - fish, non-fish sea objects and products from them. 
The following methods were used to solve theoretical problems: analysis, comparison, generalization, and description. The assessment of the contribution of iodine-containing products to the nutritional value of the diet was carried out on the basis of functionalphysical and functional-cost analysis methods

Determination of iodine content in food samples - method of inversion voltammetry according to MU 08-47/112A.

The purpose of the study is to develop indicators for assessing the contribution of iodine-containing products to the human diet in order to improve the completeness of information about actual nutrition, as the first stage of nutrition epidemiology. Obtain data on deviations of the actual iodine content in the study objects from the reference data for their updating and accounting for calculations.

\section{Results and their discussion}

The effectiveness of methods for preventing iodine deficiency and optimizing diets and body security depends on the choice and accuracy of methods used at each stage of nutrition epidemiology. The choice of methods for iodine deficiency prevention should begin with the study and update of data on the group of iodine-containing foods. The largest amount of iodine in $100 \mathrm{~g}$ of the product contains marine fish species and non-fish sea products [8].

In Russia, fish products do not occupy a leading position in the diet. On average, there are $12-17 \mathrm{~kg}$ of fish per person per year, with the recommended rate of $22 \mathrm{~kg}$. The population of the Central part of Russia receives much less with the diet.

The biological value of fish depends on the species and its habitat. The protein content is from 10 to $25 \%$; fish proteins are complete and the percentage of digestibility is higher than that of meat $(95 \%$ vs. $88 \%$ ), especially the high content of methionine (about 500 $\mathrm{mg} \%$ ) is noted. The structure of fish is characterized by a lower content of connective tissue compared to meat, and therefore more gentle heat treatment is required for cooking fish dishes. Fish, especially marine fish, contains a significant amount of extractive compounds, turning off amino acids and amines.

The fat content of fish varies widely from 2 to $12 \%$. Fish lipids are rich in polyunsaturated fatty acids. The vitamin composition of fish includes B group vitamins and a large amount of fat-soluble vitamins A and D. Special attention should be paid to the mineral composition of fish, mainly a diverse content of trace elements. Such as iodine (20$150 \mathrm{mcg} \%)$, fluorine (140-700 $\mathrm{mcg} \%$ ), bromine (40-50 mcg\%), zinc, nickel, molybdenum, etc. High content of iodine in fish makes it a priority product for iodine deficiency prevention $[9,10]$.

The dynamics of fishing (production and import) from 2011 to 2017 is shown in figure 1. 


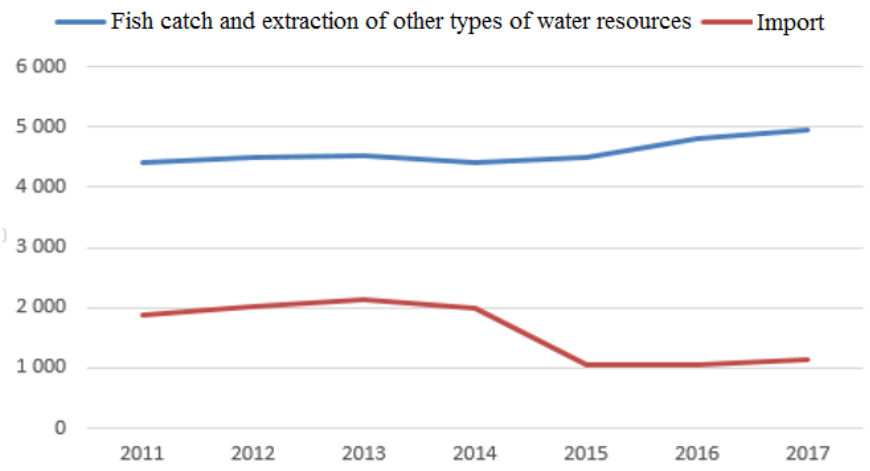

Fig. 1. Fisheries resources.

It is shown that the overall dynamics of fishing in Russia is on the rise. However, the positive dynamics of fishing has exposed the problem of the lack of production facilities for raw materials processing and storage in coastal areas [11]. As a result, violation of storage and transportation rules leads to a decrease in the nutritional value of fish and products based on it.

Algae - a group of products that encompasses multicellular, benthic marine algae. They were originally eaten by coastal residents, especially East Asians, but in the context of cultural integration and globalization, algae has gained worldwide popularity along with Asian cuisine. Algae is widely used in therapeutic and preventive nutrition, as it has a high content of calcium, magnesium and iodine.

Algae is a food product made from brown algae kelp. The main iodine source in the diet of modern man. To fill the daily requirement, it is enough to consume $40 \mathrm{~g}$ of kelp.

To assess the iodine-replenishing potential of raw fish and non-fish sea foods from the human diet, indicators were developed that account along with the content of iodine in 100 $\mathrm{g}$ of product, the factors that directly or indirectly affect the digestibility and economic feasibility of a specific fish product. The factors contributing to the increase iodinereplenishing potential product are the following: native iodine content in the product; nutrients, qualitative and quantitative composition which will have a positive influence on the thermal stability of the iodine absorption in the body.

To describe the mathematical dependence of the economic and biological effectiveness of fish products for iodine deficiency prevention, 4 indicators of the products iodinereplenishing potential were developed [12].

$\mathrm{P}_{1}{ }^{\mathrm{I}}$ is an indicator that mathematically describes the ratio of iodine content and price. It allows to evaluate the economic feasibility of using this product for iodine deficiency prevention.

$$
\mathrm{P}_{1}^{I}=\frac{m_{I}}{P},
$$

where $m_{i}$ is the total iodine content in the product or raw material, $\mu \mathrm{g} / 100 \mathrm{~g}$ of the product.

$\mathrm{P}$ - market value of the product for $100 \mathrm{~g}$.

$\mathrm{P}_{2}{ }^{\mathrm{I}}$ is an indicator that mathematically describes the ratio of the iodine content and the energy value of the product. It allows to evaluate the possibility of providing daily iodine requirements without exceeding the total daily caloric content.

$$
\mathrm{P}_{1}^{I}=\frac{m_{I} * 100}{\mathrm{Kcal}},
$$


where $m_{i}$ is the total iodine content in the product or raw material, $\mu \mathrm{g} / 100 \mathrm{~g}$ of the product. To simplify the analysis of products for this indicator, an additional numeric multiplier $(* 100)$ is introduced.

$\mathrm{Kcal}$ - energy value per $100 \mathrm{~g}$ of product.

$\mathrm{P}_{3}{ }^{\mathrm{I}}$ is an indicator that mathematically describes the ratio of iodine content, price, and energy value. It allows to evaluate the economic feasibility of using this product for iodine deficiency prevention, together with the possibility of ensuring the full daily demand for iodine without significantly increasing the total caloric content of the diet.

$$
\mathrm{P}_{3}^{I}=\frac{m_{I^{*}} 100}{\mathrm{Kcal}+10 * \mathrm{P}},
$$

where $m_{i}$ is the total iodine content in the product or raw material, $\mu \mathrm{g} / 100 \mathrm{~g}$ of the product. This factor is the most significant in comparison with the price and energy value of the product, in this regard, an additional multiplier $(* 100)$ was introduced.

Kcal - energy value per $100 \mathrm{~g}$ of product.

$\mathrm{P}$ - market value of the product for $100 \mathrm{~g}$. This factor is more significant in comparison with the energy value, so we introduce a correction factor $(* 10)$.

$\mathrm{P}_{4}{ }^{\mathrm{I}}$ is an indicator that mathematically describes the ratio of the iodine content, price, energy value and nutrients content, the presence of which has a positive effect on the digestibility of iodine, its stability during heat treatment. It allows to assess the economic feasibility of using this product for iodine deficiency prevention, the possibility of ensuring the full daily demand for iodine without significantly increasing the total caloric content of the diet, to assess the completeness of iodine absorption and its safety.

$$
\mathrm{P}_{4}^{I}=\frac{m_{I} * 10+0,01 * \mathrm{~A}+\mathrm{E}+\mathrm{B}}{\mathrm{Kcal}+10 * \mathrm{P}},
$$

where $m_{i}$ is the total iodine content in the product or raw material, $\mu \mathrm{g} / 100 \mathrm{~g}$ of the product. This factor is the most significant in comparison with the price and energy value of the product, in this regard, an additional multiplier $(* 10)$ was introduced.

Kcal - energy value per $100 \mathrm{~g}$ of product.

$\mathrm{P}$ - market value of the product for $100 \mathrm{~g}$. This factor is more significant in comparison with the energy value, so we introduce a correction factor $(* 10)$.

B - total amount of protein in the product. Protein is necessary for the most complete absorption of iodine by the body, which plays an important role in iodine deficiency prevention.

A - vitamin A content in the product.

$\mathrm{E}$ - vitamin E content in the product. The content of fat-soluble vitamins has a positive effect on the absorption of iodine in the body and its stability during heat treatment. To simplify the calculation, enter a multiplier of 0.01 for vitamin A.

On the basis of formulas 1,2,3 and 4, indicators of the contribution of fish products and non-fish sea products to ensuring the daily demand of iodine in the diet were calculated $[9,10]$.

The average protein content, iodine content, average wholesale price, and indicators of the iodine-replenishing potential for some fish species and non-fish sea products are presented in table $2[9,10]$.

Table 2. Indicators of iodine-replenishing potentials of the main fish species and non-fish products

\begin{tabular}{|c|c|c|c|c|c|c|c|c|}
\hline $\begin{array}{c}\text { Product } \\
\text { name }\end{array}$ & $\begin{array}{c}\text { Protein } \\
\text { content, } \\
\%\end{array}$ & $\begin{array}{c}\text { Iodine } \\
\text { conten } \\
\mathrm{t} \mu \mathrm{g} \%\end{array}$ & $\begin{array}{c}\text { En. } \\
\text { value, } \\
\text { Kcal }\end{array}$ & $\begin{array}{c}\text { Price, RUB } \\
\text { per } 100 \mathrm{~g}\end{array}$ & $\mathrm{P}_{1}{ }^{\mathrm{I}}$ & $\mathrm{P}_{2}{ }^{\mathrm{I}}$ & $\mathrm{P}_{3}{ }^{\mathrm{I}}$ & $\mathrm{P}_{4}{ }^{\mathrm{I}}$ \\
\hline $\begin{array}{c}\text { humpbacke } \\
\mathrm{d} \text { salmon }\end{array}$ & 20.5 & 50 & 140 & 22 & 2.3 & 3.57 & 13.9 & 1.5 \\
\hline
\end{tabular}




\begin{tabular}{|c|c|c|c|c|c|c|c|c|}
\hline flounder & 15.7 & 50 & 90 & 15 & 3.3 & 5.56 & 20.8 & 2.2 \\
\hline carp & 16 & 5 & 112 & 10 & 0.5 & 0.45 & 2.4 & 0.3 \\
\hline herring & 17.7 & 40 & 135 & 13 & 3.1 & 2.96 & 15.1 & 1.6 \\
\hline catfish & 17.2 & 5 & 115 & 16 & 0.3 & 0.43 & 1.8 & 0.2 \\
\hline pike perch & 18.4 & 5 & 84 & 20 & 0.3 & 0.6 & 1.8 & 0.2 \\
\hline $\begin{array}{c}\text { chum } \\
\text { salmon }\end{array}$ & 19 & 50 & 127 & 25 & 2.0 & 3.94 & 13.3 & 1.4 \\
\hline sprat & 14.1 & 50 & 137 & 9 & 5.6 & 3.65 & 22 & 2.3 \\
\hline pollack & 15.9 & 150 & 72 & 13 & 11 & 20.8 & 74.3 & 7.5 \\
\hline capelin & 13.6 & 50 & 217 & 15 & 3.3 & 2.30 & 13.6 & 1.4 \\
\hline sea bass & 18.2 & 60 & 82 & 23 & 2.6 & 7.32 & 19.2 & 2.0 \\
\hline poutassou & 18.5 & 135 & 73 & 6 & 22.5 & 18.4 & 101 & 10.3 \\
\hline cod & 16 & 135 & 69 & 23 & 5.9 & 19.5 & 45.2 & 4.6 \\
\hline tuna & 24.4 & 50 & 139 & 25 & 2.0 & 3.60 & 12.9 & 1.3 \\
\hline scomber & 18 & 45 & 191 & 18 & 2.5 & 2.36 & 12.1 & 1.3 \\
\hline shrimp & 18.3 & 110 & 87 & 45 & 2.4 & 12.6 & 20.5 & 2.1 \\
\hline calamary & 18 & 90 & 100 & 17 & 5.3 & 9 & 33.3 & 3.4 \\
\hline mussels & 11.5 & 90 & 77 & 16 & 5.6 & 11.6 & 38 & 3.9 \\
\hline sea kale & $\mathbf{7 . 5}$ & $\mathbf{2 5 0}$ & $\mathbf{2 0 8}$ & 7 & $\mathbf{3 5 . 7}$ & $\mathbf{1 2}$ & $\mathbf{8 9 . 9}$ & $\mathbf{9 . 1}$ \\
\hline
\end{tabular}

Sea kale has the highest values of the developed indicators. According to reference data, the maximum amount of iodine in $100 \mathrm{~g}$ of the product is contained in: pollack $(150 \mu \mathrm{g})$, poutassou and cod $(135 \mu \mathrm{g})$, shrimp $(110 \mu \mathrm{g})$, calamary and mussels $(90 \mu \mathrm{g})$.

The maximum amount of iodine for 1 RUB corresponds to the following products: poutassou $(22.5 \mu \mathrm{g})$, pollack $(11.5 \mu \mathrm{g})$, cod $(5.9 \mu \mathrm{g})$ and sprat and mussels $(5.6 \mu \mathrm{g})$.

The largest amount of iodine for every $100 \mathrm{kcal}$ of energy value contains: pollack $(208.3 \mu \mathrm{g})$, cod $(195.7 \mu \mathrm{g})$, poutassou $(184.9 \mu \mathrm{g})$, Far Eastern shrimp $(126.4 \mu \mathrm{g})$, mussels $(116.9 \mu \mathrm{g})$.

According to the total energy and economic components, the best values are for the following fish species: poutassou (101.5), pollack (74), cod (45.2) and mussels (38.0).

According to the general dynamics, all marine species of fish and non-fish sea products have a higher iodine-replenishing potential. However, during transportation, storage and preparation, fish and fish products are frozen, thawed and heat treated, which can lead to a decrease in the iodine content by $30-70 \%$.

The results of previous studies show that among other homogeneous groups of food products, some vegetables and mushrooms (champignons, radishes, lettuce, beets, cucumbers and potatoes), fruits and berries (grapes and plums), animal products (egg concentrates, egg, pork liver, beef heart, cow's milk, kefir, yogurt), cereals (beans, wheat, rye, barley) have a good iodine-replenishing potential.

The calculation method of study widely used in the study of actual nutrition has disadvantages, since it is based on averaged reference data. In each case, this data may be different. So, according to reference data, the iodine content in $100 \mathrm{~g}$ of pollack is $150 \mu \mathrm{g}$. Previously obtained data from our own research shows that the losses during defrosting and traditional methods of heat treatment reach 50-60\%. High native and reference-appropriate iodine content in sea kale, when consumed daily with the diet, may cause the risk of developing of iodine overdose symptoms and developing hypersensitivity to it. This is especially true for the part of the population living in the Central part of Russia, for which high and frequent consumption of fish is not typical. This complicates the calculation of the required product amount to meet the daily demand.

To improve the accuracy of the results of the study of actual nutrition by calculation methods and the effectiveness of using products with high values of indicators for assessing the contribution of iodine-containing foods to the nutritional value of the diet, it is 
necessary to update data on the content of iodine per $100 \mathrm{~g}$ of the product. It is also important to take into account the specific endemicity of the region for iodine.

Experimental studies of the actual iodine content in products with high values of the developed indicators were carried out (table 3). Comparative assessment was carried out to identify the percentage of deviation that should be taken into account when studying the nutritional value of diets $[9,10]$.

Table 3. Comparative characteristics of the iodine content in some food products.

\begin{tabular}{|c|c|c|c|c|}
\hline & $\begin{array}{c}\text { Iodine content } \\
\text { according to } \\
\text { reference data, } \\
\mu \mathrm{g} \%\end{array}$ & $\begin{array}{c}\text { Actual iodine } \\
\text { content, } \mu \mathrm{g} \% *\end{array}$ & $\begin{array}{c}\text { Difference between } \\
\text { reference and } \\
\text { actual values, } \Delta\end{array}$ & $\begin{array}{c}\text { Deviation from } \\
\text { the data } \\
\text { of reference } \\
\text { book, } \%\end{array}$ \\
\hline Dried kelp & 400 & 303.1 & 96.9 & $24.23 \%$ \\
\hline Marinated kelp & 250 & 189.4 & 60.6 & $24.24 \%$ \\
\hline Pollack & 150 & 102.1 & 47.9 & $31.93 \%$ \\
\hline Poutassou & 135 & 96.5 & 39 & $28.89 \%$ \\
\hline Shrimp & 110 & 50.2 & 60 & $54.55 \%$ \\
\hline Calamary & 90 & 73.0 & 17 & $18.89 \%$ \\
\hline Mussels & 90 & $-* *$ & - & - \\
\hline
\end{tabular}

* - method of iodine detection in food products provides for displaying the average value on the computer screen based on the results of at least 3 voltammograms

** - this method did not allow to determine the iodine content in mussels.

Kelp is a product with a high content of iodine, which is not exposed to rough effects, so it fits well into programs for iodine deficiency prevention. The actual iodine content in dried kelp was $303 \mu \mathrm{g} / 100 \mathrm{~g}$, in marinated - $189 \mu \mathrm{g} / 100 \mathrm{~g}$. It should be considered that high iodine content due to impaired digestibility can lead to negative consequences, such as: allergic reactions and hypersensitivity to iodine. In pollack, the iodine content was found to be $102 \mu \mathrm{g} / 100 \mathrm{~g}$, with a deviation of $32 \%$ compared to reference data. Perhaps this is a consequence of fish freezing and thawing.

\section{Conclusions}

Thus, the research results have provided new knowledge about the assessment of the contribution of iodine-containing products to the overall value of the diet in order to improve the completeness of information about actual nutrition as the first stage of nutrition epidemiology. Four indicators for assessing the contribution of iodine-containing products to the human diet have been developed. P1 - reflects the amount of iodine that the consumer receives for 1 RUB of the product. P2 - shows how much iodine is contained in 100 kilocalories obtained by the body from food. P3 - shows how effective the use of this product is for iodine replenishment in the body from the point of view of the economic and energy component. P4 - reflects the totality of factors that can affect the digestibility of iodine and economic value (food and energy value, price).

The analysis of iodine-replenishing potential of fish and non-fish sea products was carried out, on the basis of which it was revealed: the maximum amount of iodine for 1 RUB contain fish products in a number of from $22.5 \mu \mathrm{g}$ to $5.6 \mu \mathrm{g}$ : poutassou, pollack, cod, sprat and mussels;

- the maximum amount of iodine for every $100 \mathrm{kcal}$ of the product energy value contains from $208.3 \mu \mathrm{g}$ to $116.9 \mu \mathrm{g}$ : pollack, cod, poutassou, Far Eastern shrimp, mussels;

- According to the total energy and economic components, the best values are for the following fish species: poutassou (101.5), pollack (74), cod (45.2) and mussels (38.0). 
The revealed deviations of the reference data on iodine content in fish and non-fish products (six items) ranged from $18.89 \%$ to $54.55 \%$, which can be considered as a significant loss. This requires the development of measures to prevent losses, or to compensate for these losses in effective ways.

\section{References}

1. L.A. Mayurnikova, A.A. Koksharov, T.V. Krapiva, S.V. Novoselov, Food Processing: Techniques and Technology, 56(1), 124-139 (2020)

2. V.B. Spirichev, L.N. Shatnyuk, O.V. Bol'shakov, N.D. Voitkevich, Pishchevaya Promyshlennost', 4, 57-59 (2000)

3. M.M. Gapparov, VoprosyPitaniia, 68(2), 3, (2010)

4. L.A. Suplotova, O.B. Makarova, G.V. Sharukho, L.S. Kovalzhina, VoprosyPitaniya, 87(5), 27-36 (2018)

5. Gregory A. Gerasimov, "Thyroid Disorders Associated with Iodine Deficiency in Practice of Endocrinologists", ProblemyEndokrinologii, (2017)

6. O.V. Sazonova, L.M. Borodina, A.V. Galitskaya, I.F. Sukhacheva, E.M. Yakunova, Profilakticheskaya Meditsina, (1), 36-39 (2015)

7. J. Knowles, F. van der Haar, M. Shehata, G. Gerasimov, B. Bimo, B. Cavenagh, C.C. Maramag, E. Otico, D. Izwardy, R. Spohrer, G.S. Garrett, Nutrients, 9(8), E797 (2017)

8. C.C. Hicks, P.J. Cohen, N.A.J. Graham, et al. Nature, 574(7776), 95-98 (2019)

9. V.A. Tutelyan, Chemical composition and caloric content of Russian food products: Handbook (Moscow: DeLi plus, 2012)

10. I.M. Skurikhina, M.N. Volgareva, Chemical composition of food products, Reference tables of amino acids, fatty acids, vitamins, macro- and micro-elements, organic acids and carbohydrates (M.: Agropromizdat, 1987)

11. V.V. Samoylenko, Russ J Mar Biol, 45, 525-535 (2019)

12. L.A. Mayurnikova, A.Yu. Kozhevnikova, I.A. Kilina, S.V. Novoselov, Polzunovsky bulletin, 3, 63-70 (2019) 